\title{
ANALISIS PERUBAHAN SUHU PERMUKAAN TANAH DENGAN MENGGUNAKAN CITRA SATELIT TERRA DAN AQUA MODIS (Studi Kasus : Daerah Kabupaten Malang dan Surabaya)
}

\author{
Dawamul Arifin, Bangun Muljo Sukojo \\ Program Studi Teknik Geomatika FTSP-ITS, Kampus ITS Sukolilo, Surabaya, 60111 \\ Email : dawam@geodesy.its.ac.id
}

\begin{abstract}
Abstrak
Salah satu dampak pemanasan global adalah terjadinya perubahan iklim yang signifikan. Perubahan iklim yang terjadi mengakibatkan bencana hidro-meteorologi yaitu kekeringan dimana salah satu faktor terjadinya adalah peningkatan suhu permukaan tanah. Data suhu permukaan tanah di Indonesia diperoleh dari stasiun pengamat cuaca yang didapatkan dengan menggunakan termometer yang dipasang dalam sangkar cuaca. Data yang diperoleh dari pengamatan termometer ini hanya mewakili daerah sekitar.
\end{abstract}

Dalam penelitian ini, data suhu permukaan tanah didapat dengan mengunakan metode penginderaan jauh dengan memanfaatkan data citra satelit Terra Moderate Resolution Imaging Spectroradiometer (MODIS) dan Aqua MODIS serta menggunakan algoritma Li \& Becker. Penelitian ini dilakukan di daerah Kabupaten Malang dan Surabaya.

Hasil dari penelitian menunjukkan bahwa selama tahun 2008-2010 terjadi perubahan suhu permukaan tanah di Kabupaten Malang dan Surabya secara dinamis. Dari perbandingan antara data hasil pengukuran lapangan dengan hasil pengolahan data citra satelit MODIS diperoleh nilai koefisien determinasi $\left(R^{2}\right)=0,4774$ dan nilai korelasi $(R)=$ $0,6909(69,09 \%)$ dengan nilai RMSE $=3,6{ }^{\circ} \mathrm{C}$ untuk data citra satelit Terra MODIS serta $R^{2}=0,6451$ dan $R=0,7906$ $(79,06 \%)$ dengan nilai RMSE $=6,4{ }^{\circ} \mathrm{C}$ untuk data citra satelit Aqua MODIS.

Kata kunci : Terra, Aqua, MODIS, Suhu Permukaan Tanah

\section{PENDAHULUAN}

\section{Latar Belakang}

Pemanasan Global (Global Warming) merupakan isu global yang memiliki dampak besar bagi dunia. Salah satu dampaknya adalah terjadinya perubahan iklim yang signifikan. Perubahan iklim tersebut telah mengubah pola presipitasi dan evaporasi sehingga berpotensi menimbulkan banjir di beberapa lokasi dan kekeringan di lokasi yang lain.

Indonesia sebagai negara beriklim tropis juga tidak lepas dari dampak perubahan iklim yang mengakibatkan bencana hidro-meteorologi yaitu kekeringan. Salah satu faktor yang berpengaruh pada tingkat kekeringan adalah suhu permukaan tanah yang memberikan sumbangan dampak pada tingkat kekeringan dan berkurangnya pasokan air yang ada. Hal ini akan menjadi suatu permasalahn serius apabila tidak ditanggapi secara cepat dan tepat. Oleh karena itu, informasi mengenai suhu permukaan ini menjadi penting dalam penggunaanya untuk mitigasi bencana dan pengelolaan bidang yang terkait (kekeringan dan pasokan air).

Suhu permukaan tanah merupakan parameter kunci keseimbangan energi pada permukaan. Data suhu permukaan tanah sering diperlukan dalam model - model perhitungan evapotranspirasi, kelembaban udara dan neraca energi. Data suhu permukaan tanah dapat diperoleh dari stasiun pengamat cuaca akan tetapi tidak semua stasiun cuaca memiliki alat pengukur suhu permukaan tanah. Pengamatan suhu permukaan tanah oleh stasiun cuaca dilakukan dengan menggunakan termometer yang dipasang dalam sangkar cuaca. Data yang diperoleh dari pengamatan termometer ini hanya mewakili daerah sekitar. Untuk mendapatkan data suhu yang lebih luas, maka perlu mengumpulkan data data pengamatan dari beberapa stasiun.

Dengan adanya teknologi penginderaan jauh kini pengamatan suhu permukaan tanah bisa 
mencakup daerah yang lebih luas. Salah satu teknologi berbasis penginderaan jauh tersebut adalah satelit Terra dan Aqua yang membawa sensor MODIS (Moderate Resolution Imaging Spectroradiometer) yang memiliki cakupan area yang luas yakni $2330 \mathrm{~km}^{2}$ dan memiliki 36 band dengan resolusi spasial sebesar $250 \mathrm{~m}$ (band 1 dan 2), $500 \mathrm{~m}$ (band 3 - 7) dan $1000 \mathrm{~m}$ (band 8 36) dimana dari 36 band tersebut terdapat band yang secara spesifik digunakan untuk mengekstraksi suhu permukaan tanah dari citra satelit yaitu band 31 dan 32 .

Penelitian ini dilakukan di daerah Kabupaten Malang dan Kodya Surabaya Provinsi Jawa Timur. Dimana di Provinsi Jawa Timur pada tahun 2011 terjadi kekeringan di 20 kabupaten dari 29 kabupaten yang ada (Pemprov Jatim 2011) dan dari 20 kabupaten tersebut, Kabupaten Malang dan Kodya Surabaya termasuk didalamnya. Dengan kekeringan yang terjadi pada Kabupaten Kabupaten tersebut maka akan timbul dampak dalam beberapa bidang khususnya pertanian yang menjadi sektor andalan di Kabupaten Malang dan potensi tambak yang menjadi bagian penting dari Kodya Surabaya.

\section{Perumusan Masalah}

Perumusan masalah dalam penelitian ini adalah :

"Bagaimana melakukan analisa perubahan suhu permukaan tanah yang terjadi di daerah Kabupaten Malang dan Kodya Surabaya dengan menggunakan citra satelit Terra dan Aqua MODIS ?"

\section{Batasan Masalah}

Batasan masalah dari penelitian ini adalah :

1. Wilayah studi adalah daerah Kabupaten Malang dan Kodya Surabaya.

2. Data citra satelit yang digunakan adalah citra satelit Terra dan Aqua MODIS bulan Agustus 2008, 2009 dan 2010.

3. Data pembanding yang digunakan untuk analisis adalah data suhu permukaan tanah Provinsi Jawa Timur dari Badan Meteorologi, Klimatologi dan Geofisika (BMKG).

\section{Tujuan Penelitian}

Tujuan penelitian ini adalah :
1. Membuat peta suhu permukaan tanah daerah di Kabupaten Malang dan Kodya Surabaya dengan menggunakan citra Terra dan Aqua MODIS yang diambil pada bulan Agustus tahun 2008, 2009 dan 2010.

2. Menganalisis perubahan suhu permukaan tanah dari peta suhu permukaan tanah dari daerah Kabupaten Malang dan Kodya Surabaya dengan menggunakan citra Terra dan Aqua MODIS yang diambil pada bulan Agustus tahun 2008, 2009 dan 2010.

\section{Manfaat}

Manfaat yang dapat diperoleh dari penelitian ini adalah mampu memberikan suatu informasi mengenai suhu permukaan tanah di daerah Kabupaten Malang dan Kodya Surabaya yang diperoleh dari analisis hasil pengolahan citra Terra dan Aqua MODIS untuk kepentingan pertanian, pengairan dan bencana alam.

\section{METODOLOGI PENELITIAN}

\section{Lokasi Penelitian}

Lokasi penelitian adalah daerah Kabupaten Malang dan Kodya Surabaya. Periode pengamatan suhu permukaan tanah berdasarkan data citra satelit Terra dan Aqua MODIS adalah bulan Agustus tahun 2008, 2009 dan 2010.

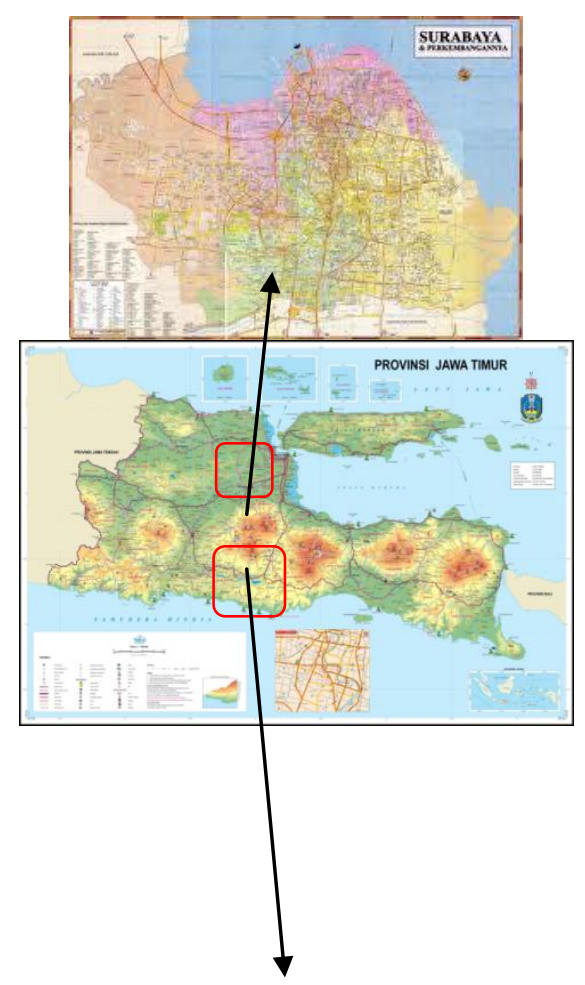




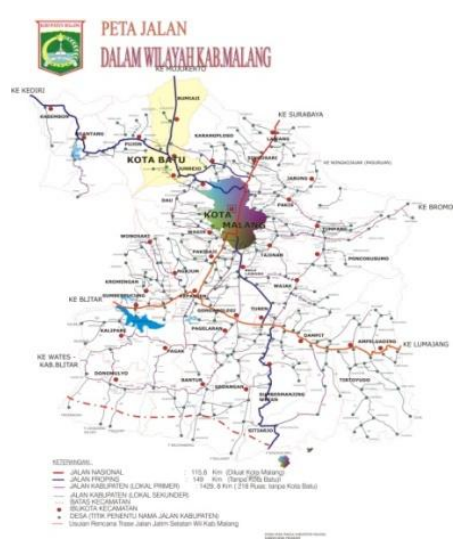

Gambar 2.1 Lokasi Penelitian

\section{Data dan Peralatan}

\section{- Data}

Data yang digunakan dalam penelitian ini adalah:

1. Data Citra satelit Terra dan Aqua MODIS bulan Agustus tahun 2008, 2009 dan 2010.

2. Data peta administrasi Indonesia skala 1 : 1.000.000.

3. Data suhu permukaan tanah Provinsi Jawa Timur (Surabaya dan Malang) dari Badan Meteorologi, Klimatologi dan Geofisika (BMKG).

\section{- Peralatan}

Peralatan yang digunakan dalam penelitian ini adalah:

1. Perangkat Keras (Hardware)
a. Laptop

2. Perangkat Lunak (Software)
a. ENVI 4.6.1
b. Matlab 7.0.1

\section{Diagram Alir Pengolahan Data}

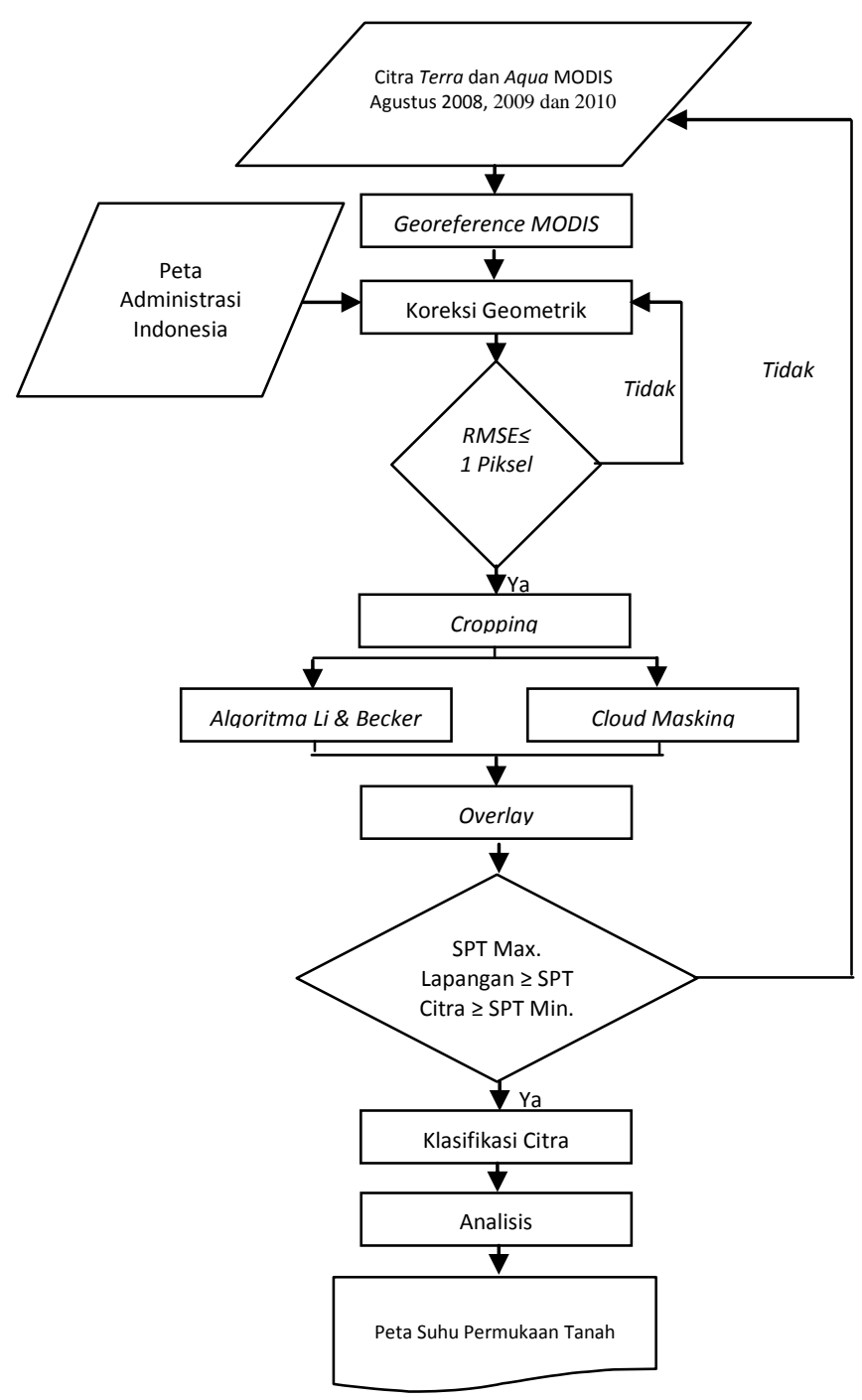

Gambar 2. Diagram Tahap Pengolahan Data

Penjelasan dari diagram alir penelitian diatas adalah :

1. Input data citra satelit Terra dan Aqua MODIS yang diperoleh dari http://modis.gsfc.nasa.gov/ untuk dilakukan proses pengolahan agar diperoleh nilai suhu permukaan tanahnya.

2. Proses georeferencing dan koreksi geometrik dilakukan pada citra yang telah di-input-kan agar citra awal memiliki posisi sesuai dengan kondisi yang sebenarnya di bumi. Untuk proses koreksi geometrik digunakan peta administrasi Indonesia skala 1:1000.000 sebagai acuan. Toleransi yang digunakan yaitu Root Mean Square Error (RMSE) - nya harus $\leq 1$ piksel, apabila melebihi maka koreksi tersebut harus 
diulang. Jaring yang digunakan dalam koreksi geometrik terlebih dahulu dihitung kekuatan jaringnya (strength of figure) dimana nilai kekuatan jaring bernilai semakin baik jika mendekati 0 .

3. Citra yang telah terkoreksi geometrik kemudian di-cropping dengan menggunakan fasilitas Region Of Interest (ROI) pada software ENVI yang bertujuan untuk memfokuskan proses pengolahan citra pada area studi.

4. Data citra satelit yang diperoleh tidak $100 \%$ terbebas dari tutupan awan sehingga perlu dipisahkan dengan melakukan fungsi cloud masking yang merupakan proses untuk memisahkan awan dengan memanfaatkan panjang gelombang pada band 3. Pada ENVI dapat dilakukan dengan menggunakan fungsi band math pada sub menu bar basic tools.

5. Algoritma Li \& Becker digunakan untuk memperoleh nilai suhu permukaan tanah dengan menggunakan fungsi band math pada sub menu bar basic tools di ENVI. Algoritma yang dituliskan pada ENVI adalah sebagai berikut :

float $((1,274+(1,001323452 *(((B 1)+(B 2)) / 2))+(6$, $267075477 *(((B 1)-(B 2)) / 2)))-273)$

dimana B1 adalah pendefinisian untuk band 31 pada MODIS dan B2 didefinisikan untuk band 32.

Dalam proses ini, terlebih dahulu band 31 dan 32 dirubah menjadi brightness temperature dengan menggunakan :

a. Algoritma band 31 :

float $((1,438833 * 10000) /(11,017 * \operatorname{alog}(((1,1$ $\left.\left.\left.\left.\left.910659 * 100000000) /\left(11,017^{\wedge} 5^{*} \mathrm{~B} 31\right)\right)+1\right)\right)\right)\right)$

b. Algoritma band 32 :

float $((1,438833 * 10000) /(12,032 * \operatorname{alog}(((1,1$ 910659*100000000)/(12,032^5*B32))+1))))

6. Uji ketelitian suhu permukaan tanah hasil pengolahan citra dilakukan dengan melihat apakah hasil suhu permukaan tanah tersebut bernilai diantara nilai suhu permukaan tanah minimum dan maksimum dari data pengamatan lapangan. Hal itu juga bisa dituliskan menjadi sebagai berikut:

Suhu permukaan tanah maksimum dilapangan $\geq$ Suhu permukaan tanah hasil pengolahan citra $\geq$ Suhu permukaan tanah minimum dilapangan.
7. Proses klasifikasi dengan menganalisis sejumlah piksel berdasarkan digital numbernya. Proses ini dilakukan dengan menggunakan fasilitas band threshold to ROI pada ENVI dimana proses ini akan membagi data suhu permukaan tanah hasil pemrosesan citra kedalam beberapa kelas.

8. Pada tahap analisis, dilakukan analisa tentang perubahan suhu yang terjadi dan membandingkan hasil pengolahan citra satelit Terra dan Aqua MODIS.

9. Dari pengolahan data citra dan analisis yang dilakukan diperoleh hasil akhir berupa peta suhu permukaan tanah dari citra satelit Terra dan Aqua MODIS.

\section{HASIL DAN PEMBAHASAN}

\section{Pemilihan Data}

Pemilihan data dilakukan untuk mendapatkan data citra yang bebas dari tutupan awan. Karena pada penelitian ini tidak didapatkan citra yang benar-benar bebas dari tutupan awan, maka pada penelitian ini menggunakan data citra dengan tutupan awan yang relatif sedikit. Dari pemilihan diperoleh citra Terra dan Aqua MODIS yang ditunjukkan pada tabel berikut.

Tabel 1. Data Citra Terra dan Aqua MODIS

\begin{tabular}{|c|c|c|c|}
\hline No & Tahun & Nama Data & Keterangan \\
\hline 1 & 2008 & $\begin{array}{c}\text { MOD021KM.A2008217.02 } \\
20.005 .2010247065404\end{array}$ & Terra - MODIS \\
\hline 2 & 2008 & $\begin{array}{c}\text { MOD021KM.A2008225.03 } \\
10.005 .2010247092801\end{array}$ & Terra - MODIS \\
\hline 3 & 2008 & $\begin{array}{c}\text { MOD021KM.A2008238.02 } \\
40.005 .2010247231956\end{array}$ & Terra - MODIS \\
\hline 4 & 2009 & $\begin{array}{c}\text { MOD021KM.A2009213.02 } \\
55.005 .2010248073912\end{array}$ & Terra-MODIS \\
\hline 5 & 2009 & $\begin{array}{c}\text { MOD021KM.A2009231.02 } \\
45.005 .2010249115936\end{array}$ & MODIS \\
\hline 6 & 2009 & $\begin{array}{c}\text { MOD021KM.A2009240.02 } \\
40.005 .2010250030233\end{array}$ & Terra - MODIS \\
\hline 7 & 2010 & $\begin{array}{c}\text { MOD021KM.A2010213.02 } \\
25.005 .2010213134234\end{array}$ & Terra - MODIS \\
\hline 8 & 2010 & $\begin{array}{c}\text { MOD021KM.A2010221.03 } \\
\text { 15.005.2010229204222 }\end{array}$ & Terra - MODIS \\
\hline 9 & 2010 & $\begin{array}{c}\text { MOD021KM.A2010239.03 } \\
05.005 .2010239141033\end{array}$ & Terra - MODIS \\
\hline 10 & 2008 & $\begin{array}{c}\text { MYD021KM.A2008216.061 } \\
0.005 .2009319221548\end{array}$ & Aqua-MODIS \\
\hline 11 & 2008 & $\begin{array}{c}\text { MYD021KM.A2008214.062 } \\
0.005 .2009319171331\end{array}$ & Aqua-MODIS \\
\hline 12 & 2008 & $\begin{array}{c}\text { MYD021KM.A2008221.062 } \\
5.005 .2009320091814\end{array}$ & Aqua-MODIS \\
\hline
\end{tabular}




\begin{tabular}{|c|c|c|c|}
\hline No & Tahun & Nama Data & Keterangan \\
\hline 13 & 2009 & $\begin{array}{l}\text { MYD021KM.A2009213.055 } \\
5.005 .2009213212326\end{array}$ & Aqua-MODIS \\
\hline 14 & 2009 & $\begin{array}{c}\text { MYD021KM.A2009232.062 } \\
5.005 .2009232171548\end{array}$ & Aqua-MODIS \\
\hline 15 & 2009 & $\begin{array}{c}\text { MYD021KM.A2009238.054 } \\
5.005 .2009238170622\end{array}$ & Aqua-MODIS \\
\hline 16 & 2010 & $\begin{array}{c}\text { MYD021KM.A2010228.061 } \\
5.005 .2010231150934\end{array}$ & Aqua-MODIS \\
\hline 17 & 2010 & $\begin{array}{c}\text { MYD021KM.A2011236.063 } \\
0.005 .2011236184520\end{array}$ & Aqua-MODIS \\
\hline 18 & 2010 & $\begin{array}{c}\text { MYD021KM.A2010239.055 } \\
5.005 .2010239214717\end{array}$ & Aqua-MODIS \\
\hline
\end{tabular}

\section{Koreksi Geometrik dan Strength Of Figure}

Untuk koreksi geometrik dilakukan dengan menggunakan Peta Administrasi Indonesia dengan nama file Indo_kab.shp skala 1:1.000.000 berupa peta vektor milik Bakosurtanal dimana toleransi nilai RMSE untuk koreksi geometrik adalah $\leq 1$ piksel dan untuk jaring titik kontrol ditentukan dengan meletakkan titik - titik kontrol yang merata mencakup daerah studi dengan nilai SOF harus mendekati 0 . Berikut rincian perhitungan RMSE dan Strength Of Figure.

Tabel 2. Rata-Rata RMSE dan Strength Of Figure (SOF)

\begin{tabular}{|c|c|c|c|}
\hline No & Nama Data & Nilai SOF & $\begin{array}{c}\text { Nilai } \\
\text { RMSE } \\
\text { Rata-Rata }\end{array}$ \\
\hline \multirow[t]{2}{*}{1} & MOD021KM.A200821 & & \\
\hline & $\begin{array}{c}7.0220 .005 .20102470 \\
65404\end{array}$ & 0,0016 & 0,42113 \\
\hline \multirow[t]{2}{*}{2} & MOD021KM.A200822 & & \\
\hline & $\begin{array}{c}5.0310 .005 .20102470 \\
92801\end{array}$ & 0,000265 & 0,52467 \\
\hline \multirow[t]{3}{*}{3} & MOD021KM.A200823 & & \\
\hline & 8.0240 .005 .20102472 & 0,000433 & 0,62531 \\
\hline & 31956 & & \\
\hline \multirow[t]{2}{*}{4} & MOD021KM.A200921 & & \\
\hline & $\begin{array}{c}3.0255 .005 .20102480 \\
73912\end{array}$ & 0,000337 & 0,64622 \\
\hline \multirow[t]{2}{*}{5} & MOD021KM.A200923 & & \\
\hline & $\begin{array}{c}1.0245 .005 .20102491 \\
15936\end{array}$ & 0,000384 & 0,66392 \\
\hline \multirow[t]{2}{*}{6} & MOD021KM.A200924 & & \\
\hline & $\begin{array}{c}0.0240 .005 .20102500 \\
30233\end{array}$ & 0,000297 & 0,46233 \\
\hline \multirow[t]{2}{*}{7} & MOD021KM.A201021 & & \\
\hline & $\begin{array}{c}3.0225 .005 .20102131 \\
34234\end{array}$ & 0,000882 & 0,67364 \\
\hline \multirow[t]{2}{*}{8} & MOD021KM.A201022 & & \\
\hline & $\begin{array}{c}1.0315 .005 .20102292 \\
04222\end{array}$ & 0,000176 & 0,53254 \\
\hline \multirow[t]{2}{*}{9} & MOD021KM.A201023 & & \\
\hline & $\begin{array}{c}9.0305 .005 .20102391 \\
41033\end{array}$ & 0,000442 & 0,66435 \\
\hline
\end{tabular}

\begin{tabular}{|c|c|c|c|}
\hline No & Nama Data & Nilai SOF & $\begin{array}{c}\text { Nilai } \\
\text { RMSE } \\
\text { Rata -Rata }\end{array}$ \\
\hline 11 & $\begin{array}{c}\text { MYD021KM.A200821 } \\
4.0620 .005 .20093191 \\
71331\end{array}$ & 0,000514 & 0,65236 \\
\hline 12 & $\begin{array}{c}\text { MYD021KM.A200822 } \\
1.0625 .005 .20093200 \\
91814\end{array}$ & 0,000725 & 0,67354 \\
\hline 13 & $\begin{array}{c}\text { MYD021KM.A200921 } \\
3.0555 .005 .20092132 \\
12326\end{array}$ & 0,000606 & 0,57488 \\
\hline 14 & $\begin{array}{c}\text { MYD021KM.A200923 } \\
2.0625 .005 .20092321 \\
71548\end{array}$ & 0,000384 & 0,58782 \\
\hline 15 & $\begin{array}{c}\text { MYD021KM.A200923 } \\
8.0545 .005 .20092381 \\
70622\end{array}$ & 0,0011 & 0,54317 \\
\hline 16 & $\begin{array}{c}\text { MYD021KM.A201022 } \\
8.0615 .005 .20102311 \\
50934\end{array}$ & 0,000442 & 0,68273 \\
\hline 17 & $\begin{array}{c}\text { MYD021KM.A201123 } \\
6.0630 .005 .20112361 \\
84520\end{array}$ & 0,000514 & 0,53738 \\
\hline 18 & $\begin{array}{c}\text { MYD021KM.A201023 } \\
9.0555 .005 .20102392 \\
14717\end{array}$ & 0,000606 & 0,47628 \\
\hline
\end{tabular}

\section{Perbandingan Nilai Suhu Permukaan Tanah dari Citra dengan Data Lapangan}

Proses pengolahan citra dengan menggunakan algoritma Li \& Becker menghasilkan nilai suhu permukaan tanah pada piksel lokasi stasiun pengamatan berada dengan nilai sebagai berikut :

Tabel 3. Nilai SPT Rata - Rata Data Lapangan

\begin{tabular}{|c|c|c|c|c|}
\hline \multirow[t]{2}{*}{ No } & \multirow[t]{2}{*}{ Lokasi } & \multicolumn{3}{|c|}{$\begin{array}{c}\text { Data SPT Rata - Rata } \\
\text { Lapangan }\end{array}$} \\
\hline & & 2008 & 2009 & 2010 \\
\hline 1 & $\begin{array}{l}\text { Stasiun Geofisika } \\
\text { Karangkates }\end{array}$ & 24,5 & 24,3 & 25,3 \\
\hline 2 & $\begin{array}{l}\text { Stasiun Klimatologi } \\
\text { Karangploso }\end{array}$ & 19,1 & 22,3 & 23,4 \\
\hline 3 & $\begin{array}{c}\text { Stasiun Meteorologi } \\
\text { Maritim }\end{array}$ & 28,5 & 28,8 & 29,2 \\
\hline
\end{tabular}


Tabel 4. Nilai SPT Rata-Rata Hasil Pengolahan Citra Terra-MODIS

\begin{tabular}{ccccc}
\hline \multirow{4}{*}{ No } & Lokasi & \multicolumn{3}{c}{ Nilai SPT Rata - Rata Citra Terra } \\
& & 2008 & 2009 & 2010 \\
\hline 1 & $\begin{array}{c}\text { Stasiun Geofisika } \\
\text { Karangkates } \\
\text { Stasiun Klimatologi } \\
\text { Karangploso } \\
\text { Stasiun }\end{array}$ & 27,073 & 32,375 & 28,541 \\
& 20,659 & 21,699 & 18,813 \\
3 & $\begin{array}{c}\text { Meteorologi } \\
\text { Maritim }\end{array}$ & 28,424 & 31,786 & 28,274 \\
\hline
\end{tabular}

Tabel 5. Nilai SPT Rata-Rata Hasil Pengolahan Citra Aqua-MODIS

\begin{tabular}{ccccc}
\hline \multirow{4}{*}{ No } & Lokasi & \multicolumn{3}{c}{$\begin{array}{c}\text { MODIS } \\
\text { MOta }\end{array}$} \\
\hline 1 & 2008 & 2009 & 2010 \\
\hline 2 & $\begin{array}{c}\text { Stasiun Geofisika } \\
\text { Karangkates } \\
\text { Stasiun } \\
\text { Klimatologi } \\
\text { Karangploso } \\
\text { Stasiun }\end{array}$ & 32,037 & 34,611 & 32,072 \\
& $\begin{array}{l}\text { Meteorologi } \\
\text { Maritim }\end{array}$ & 36,605 & 34,443 & 34,534 \\
\hline
\end{tabular}

Untuk nilai perbandingan yang dihasilkan dari hubungan SPT citra Terra MODIS dan SPT data lapangan, diperoleh nilai koefisien determinasi $\left(R^{2}\right)$ sebesar 0,4774 yang berarti memiliki nilai korelasi (R) sebesar 0,6909 $(69,09 \%)$ dengan nilai RMSE sebesar $3,6{ }^{\circ} \mathrm{C}$ dan untuk nilai perbandingan yang dihasilkan dari hubungan SPT citra Aqua MODIS dan SPT data lapangan, diperoleh nilai koefisien determinasi $\left(R^{2}\right)$ sebesar 0,6251 yang berarti memiliki nilai korelasi $(R)$ sebesar 0,7906 $(79,06 \%)$ dan dengan nilai RMSE sebesar $6,4{ }^{\circ} \mathrm{C}$. Besar nilai koefisien korelasi ini menunjukkan nilai keterhubungan antara data SPT lapangan dengan data SPT dari pengolahan citra satelit baik Terra dan Aqua MODIS dimana nilai ini diperoleh dari rasio kovariansi antara data SPT hasil pengolahan citra dan data SPT lapangan terhadap hasil kali simpangan baku data SPT hasil pengolahan citra dan simpangan baku data SPT lapangan. Nilai tersebut dapat dilihat seperti tampak pada gambar dibawah ini :

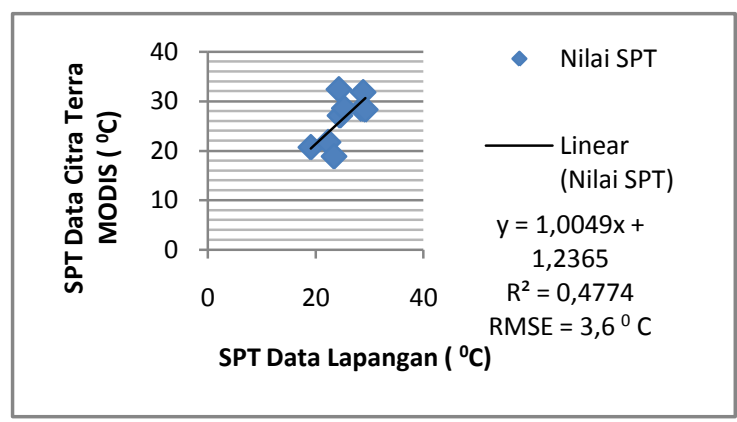
Gambar 3. Diagram Pencar dan Garis Linear SPT Terra
MODIS terhadap Data Lapangan

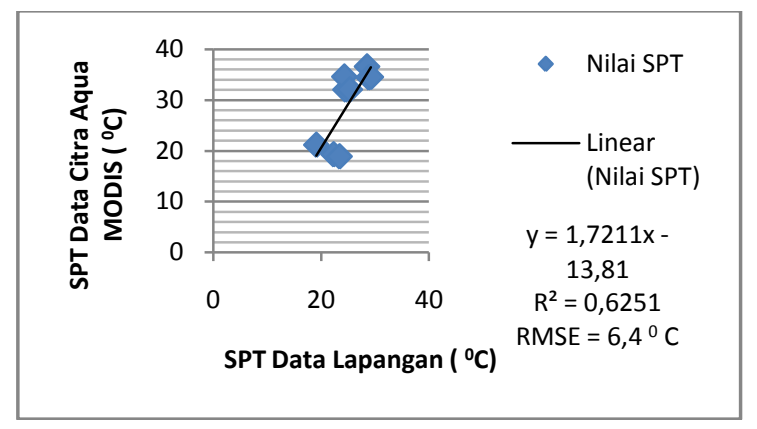

Gambar 4. Diagram Pencar dan Garis Linear SPT Aqua MODIS terhadap Data Lapangan

\section{Peta Suhu Permukaan Tanah}

Dari data citra yang telah diolah kemudian dibuat menjadi suatu peta suhu permukaan tanah seperti tampak pada gambar dibawah ini:

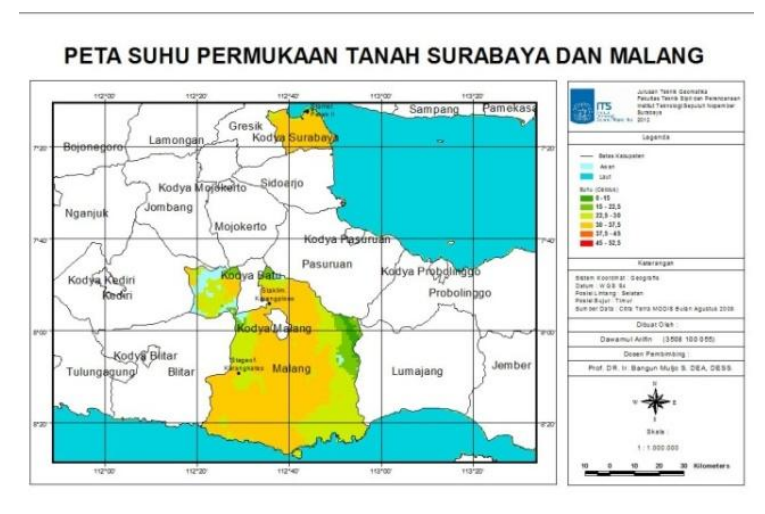

Gambar 5. Peta Suhu Permukaan Tanah Surabaya dan Malang Bulan Agustus 2008 hasil pengolahan citra Terra MODIS 


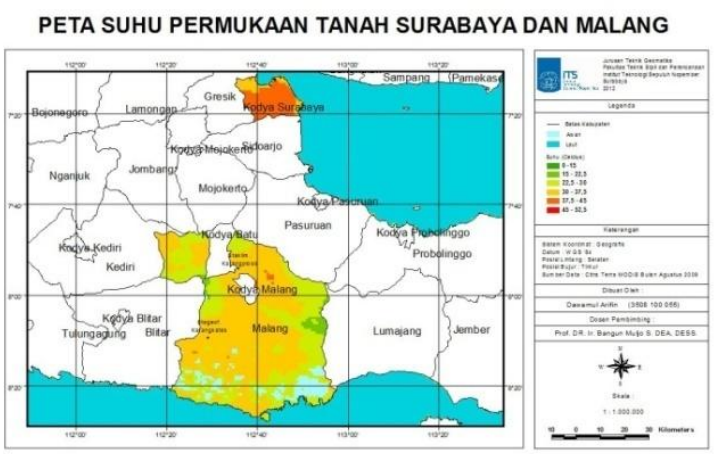

Gambar 6. Peta Suhu Permukaan Tanah Surabaya dan Malang Bulan Agustus 2009 hasil pengolahan citra Terra MODIS

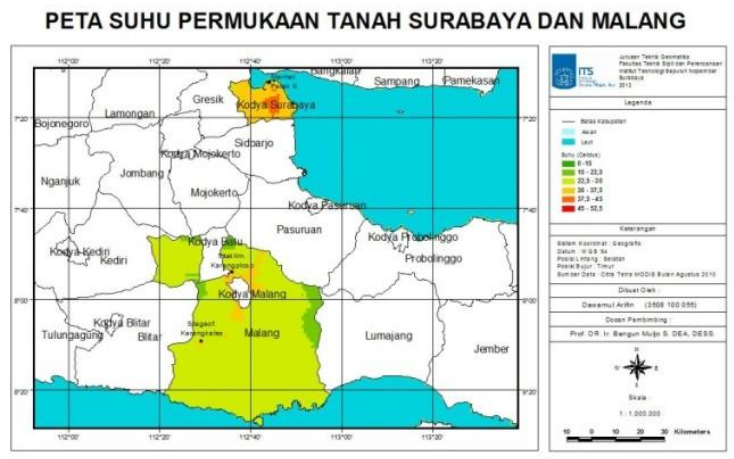

Gambar 7. Peta Suhu Permukaan Tanah Surabaya dan Malang Bulan Agustus 2010 hasil pengolahan citra Terra MODIS

PETA SUHU PERMUKAAN TANAH SURABAYA DAN MALANG

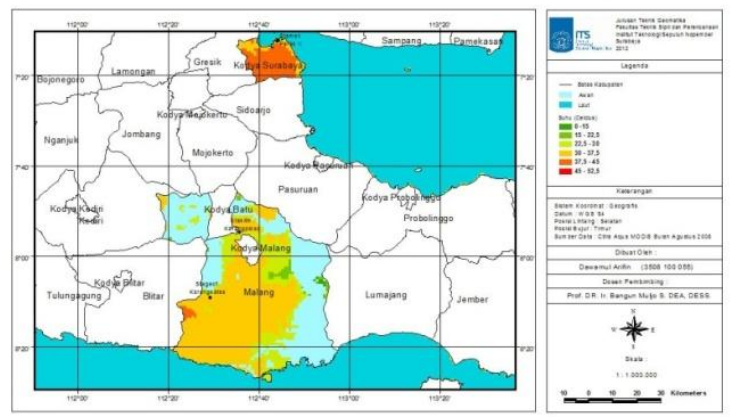

Gambar 8. Peta Suhu Permukaan Tanah Surabaya dan Malang Bulan Agustus 2008 hasil pengolahan citra Aqua MODIS
PETA SUHU PERMUKAAN TANAH SURABAYA DAN MALANG

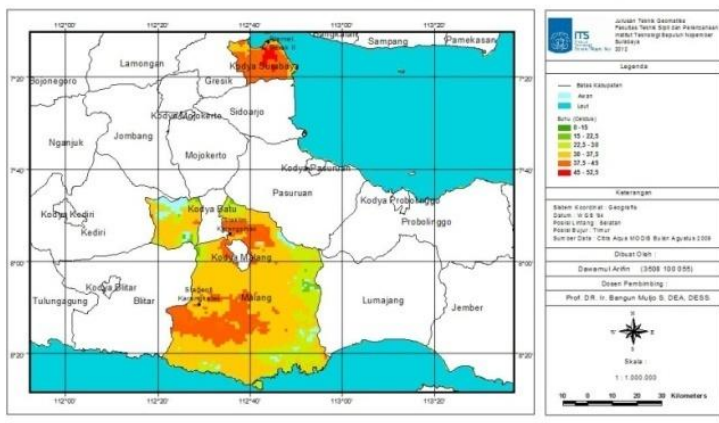

Gambar 9. Peta Suhu Permukaan Tanah Surabaya dan Malang Bulan Agustus 2009 hasil pengolahan citra Aqua MODIS

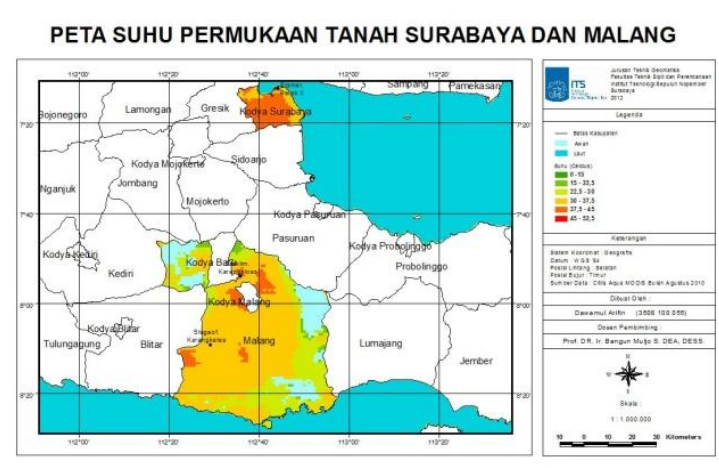

Gambar 10. Peta Suhu Permukaan Tanah Surabaya dan Malang Bulan Agustus $\mathbf{2 0 1 0}$ hasil pengolahan citra Aqua MODIS

\section{KESIMPULAN DAN SARAN}

\section{Kesimpulan}

Berdasarkan hasil penelitian tentang pemetaan SPT, maka didapatkan beberapa kesimpulan akhir dari penelitian ini, yaitu:

1. Perbandingan data SPT dari citra dengan data lapangan menunjukkan nilai koefisien determinasi (R2) sebesar 0,4774 dan nilai korelasi (R) sebesar 0,6909 (69,09\%) untuk SPT citra Terra MODIS dan data SPT lapangan serta R2 sebesar 0,6251 dan R sebesar 0,7906 $(79,06 \%)$ untuk SPT citra Aqua MODIS dan data SPT lapangan.

2. Hasil pengolahan citra Aqua MODIS menunjukkan bahwa pada tahun 2008, 2009 dan 2010 daerah Kabupaten Malang didominasi oleh daerah dengan nilai suhu 30 - 37,5 0C. Pada tahun 2009 terjadi perubahan dimana daerah dengan rentang nilai suhu 37,5 - 45 0C meluas. 
3. Untuk daerah Surabaya, hasil pengolahan citra Aqua MODIS menunjukkan bahwa pada tahun 2008, 2009 dan 2010 daerah dengan nilai suhu 37,5 - 45 OC mendominasi. Pada tahun 2009 terjadi perubahan suhu dimana muncul daerah dengan nilai suhu $45-52,50 \mathrm{C}$ dan pada tahun 2010 daerah Surabaya kembali didominasi daerah dengan nilai suhu 37,5 - 45 OC dan tidak ada daerah dengan nilai suhu diatas rentang nilai suhu tersebut.

4. Hasil pengolahan citra Terra MODIS menunjukkan bahwa pada tahun 2008 dan 2009, daerah Kabupaten Malang didominasi oleh daerah dengan nilai suhu $30-37$ OC. Akan tetapi daerah Kabupaten Malang pada tahun 2010 didominasi oleh daerah dengan nilai suhu 22,5 - 30 OC. Pada tahun 2009 terdapat daerah dengan rentang nilai suhu $37,5-450 C$ yang muncul.

5. Untuk daerah Surabaya, hasil pengolahan citra Terra MODIS menunjukkan bahwa pada tahun 2008 daerah dengan nilai suhu $30-37$ OC mendominasi. Sedangkan pada tahun 2009 terjadi perubahan suhu dimana muncul daerah dengan nilai suhu $37,5-45$ OC yang mendominasi daerah Surabaya dan pada tahun 2010 daerah Surabaya kembali didominasi daerah dengan nilai suhu $30-37$ 0.

6. Perbandingan data SPT dari citra dengan data lapangan menunjukkan nilai RMSE sebesar 3,6 OC untuk SPT hasil pengolahan citra Terra MODIS dan sebesar 6,4 OC untuk SPT hasil pengolahan citra Aqua MODIS . Hal ini menunjukkan bahwa citra Terra MODIS lebih baik dibandingkan dengan citra Aqua MODIS dalam memperoleh nilai suhu permukaan tanah.

\section{Saran}

Berdasarkan hasil pengolahan data dan kesimpulan yang diperoleh, dapat dianalisis bahwa :

1. Perlu dilakukan pemetaan suhu permukaan tanah dengan menggunakan data yang memiliki tingkat resolusi yang lebih baik, baik resolusi spasial maupun temporal.

2. Data validasi yang digunakan sebaiknya data insitu yang memiliki parameter waktu yang sama persis dengan waktu perekaman data citra satelit.

3. Untuk penelitian selanjutnya lebih baik memperhatikan unsur-unsur yang terkait dengan tingkat suhu permukaan tanah.

4. Perubahan suhu permukaan tanah yang terjadi mengharuskan bidang - bidang yang berkaitan dengan suhu untuk melakukan pengembangan atau perubahan pola atau sistem untuk mengatasi hal tersebut sehingga perubahan tersebut tidaklah memberikan pengaruh negatif sehingga kerugian yang mungkin muncul dapat diminimalisir.

5. Untuk mendapatkan nilai spektral hutan dengan ketelitian yang baik, digunakan data lapangan dengan mengukur nilai spektral hutan menggunakan spektrometer.

6. Perlu dilakukan penelitian untuk mendapatkan algoritma yang lebih spesifik untuk pendefinisian daerah hutan.

\section{DAFTAR PUSTAKA}

Abidin, H. Z., dkk. 2002. Survei Dengan Gps. Jakarta: Pradnya Paramitha.

Ariadi, W. 2007. Estimasi Evapotranspirasi Spasial Menggunakan Suhu Permukaan Darat (SPT) Dari Data MODIS TERRA / AQUA Dan Pengaruhnya Terhadap Kekeringan. Bogor : Skripsi Departemen Geofisika dan Meteorologi Fakultas Matematika dan IImu Pengetahuan Alam Institut Pertanian Bogor.

http://Ipdaac.usgs.gov/Ipdaac/products/modis_ overview. Dikunjungi pada tanggal 26 September 2011, Jam 11:10 WIB

http://modis.gsfc.nasa.gov/about/specifications .php. Dikunjungi pada tanggal 26 September 2011, Jam 11:24 WIB

http://nsidc.org/data/docs/daac/AQUA_platfor m.gd.html. Dikunjungi pada tanggal 22 Oktober 2001, Jam 20:34 WIB.

http://www.jatimprov.go.id/. Dikunjungi pada 17 Oktober 2011, Jam 15.44 WIB.

Lillesand, T.M., Kiefer, R.W., and Chipman J.W.2004. Remote Sensing and Image Interpretation. Fifth Edition. New york : John Wiley \& Sons.

Lillesand, T.M., Kiefer, R.W.1994. Remote Sensing and Image Interpretation. Fifth 
Edition. New york: John Wiley \& Suseno, W., Rokhmatullah, Wibowo, A. 2008.

Sons.

Martin, S. 2004. An Introduction to Ocean Remote Sensing. United Kingdom : University of Cambridge.

Prasasti, I., dkk. 2004. Pengkajian Nilai Indeks Vegetasi Data MODIS dengan Menerapkan Beberapa Algoritma Pengolahan Data Indeks Vegetasi

Purwadhi, S.H. 2001. Interpretasi Citra Digital. Jakarta: Grasindo

Rafi'i, Suryatna. 1995. Meteorologi dan Klimatologi. Angkasa. Bandung

Short, N. M. 1982. The Landsat Tutorial Workbook: Basics of Satellite Remote Sensing, Scientific and Technical Information Branch. NASA, Washington DC.
Ekstraksi Pola Kekeringan Pertanian Pulau Jawa Menggunakan Data Satelit NOAA-18 AVHRR.

Sutanto. 1984. Penginderaan Jauh Jilid 1. Gadjah Mada University Press. Yogyakarta.

Wan, Z., Zhang, Y., Zhang, Q., Li, Z. 2002. "Validation of the Land-Surface Temperature products Retrieved from TERRA Moderate Resolution Imaging Spectroradiometer Data". Remote Sensing of Environment 83 (March):163-180.

Wan, Z. 1999. "MODIS Land-Surface Temperature Algorithm Theoretical Basis Document (LST ATBD)", <URL:http://modis.gsfc.nasa.gov/dat

a/ atbd/ $>$, . Dikunjungi pada tanggal 20 Oktober 2011, jam 18.36. 